\author{
TADEUSZ KOŁOSOWSKI* \\ Wydział Nauk Historycznych \\ Uniwersytet Kardynała Stefana Wyszyńskiego, Warszawa \\ ORCID: 0000-0002-4019-3447
}

\title{
POST I ZAPOBIEGANIE JEGO EWENTUALNYM SKUTKOM ZDROWOTNYM W ŚWIETLE KORESPONDENCJI ŚW. HIERONIMA
}

\section{Wprowadzenie}

Korespondencja św. Hieronima pozwala poznać go jako duszpasterza, który przez osobisty kontakt, a także poprzez listy, stara się w indywidualny sposób podejść do ludzi, stosownie do czasu i sytuacji życiowych, w jakich się znaleźli. W sumie w zbiorze korespondencji związanej z życiem i działalnością św. Hieronima znajduje się I56 listów, w tym część $\mathrm{z}$ nich to listy adresowane do Hieronima przez różnych nadawców. Listy te powstawały przez okres niemal półwiecza. Pierwszy z nich został napisany w 370 r., wkrótce po tym, jak Hieronim odkrył smak życia ascetycznego w Trewirze, ostatni powstał w 4I9 r. w Betlejem, krótko przed jego śmiercią. Odzwierciedlają one jego życie od młodzieńczych wzruszeń do dojrzałych refleksji pobytu starca w klasztorze ${ }^{\mathrm{I}}$.

Poruszana przez Hieronima w listach problematyka jest bardzo różnorodna. Nie brak listów, które mają poważny charakter naukowy. Takimi są choćby listy egzegetyczne, w których wyjaśnia różne kwestie dotyczące interpretacji poszczególnych ksiąg Pisma Świętego. Przeważa jednak problematyka duszpasterska. W świetle listów Hieronim jawi się jako dobry i doświadczony kierownik życia duchowego swoich adresatów ${ }^{2}$. Udzielał im wielu porad na temat modlitwy, czytania Pisma Świętego i chrześcijańskich praktyk ascetycznych. Z listów wynika, że Hieronim troszczył się nie tylko o ich zdrowie duchowe, ale także i fizyczne. Przejawem tej troski jest nauczanie Hieronima na temat właściwego praktykowania postu w życiu chrześcijańskim. Niektórzy korespondenci Hieronima, w sposób skrajny podchodząc do praktykowania postu, wyniszczali swoje zdrowie. Hieronim z jednej strony poucza ich, jak należy rozumieć i praktykować post w znaczeniu chrześcijańskim, z drugiej na wzór

\footnotetext{
* Ks. dr hab. Tadeusz Kołosowski - doktor habilitowany, profesor nadzwyczajny w Katedrze Historii Starożytnej w Instytucie Historii na Wydziale Nauk Historycznych Uniwersytetu Kardynała Stefana Wyszyńskiego w Warszawie. E-mail: tadekolo@kn.onet.pl.

1 Por. T. Kołosowski, Święty Hieronim jako duszpasterz, „Seminare”, 20/2004, s. 453, 455.

2 Por. M. Formela, Św. Hieronim jako kierownik życia duchowego w świetle jego korespondencji. Studium historyczno-patrystyczne, rozprawa doktorska napisana pod naukowym kierownictwem ks. dra hab. Tadeusza Kołosowskiego, prof. UKSW, Warszawa 2004.
} 
dzisiejszych dietetyków stara się podsunąć właściwą dietę w taki sposób, by można było praktykować i chrześcijański post i prowadzić zdrowy tryb życia.

\section{Post w życiu i nauczaniu św. Hieronima}

Post jako dobrowolne wyrzeczenie się wybranych pokarmów, czy też rezygnacja ze spożywania czegokolwiek w określonym czasie, przyjmował w dziejach różnorakie formy. W kulturach archaicznych miał na ogół charakter okazjonalny i wiązał się np. z żałobą czy też z inicjacją. W cywilizacji grecko-rzymskiej post zdarzał się rzadko. W życiu religijnym starożytnych Greków i Rzymian wstrzemięźliwość od pokarmów i napojów nie odgrywała większej roli. Wegetarianizm praktykowany w kręgach filozoficznych nie miał podłoża religijnego czy moralnego, ale jedynie zdrowotne czy higieniczne. Post był natomiast uregulowany prawem religijnym w judaizmie. Związany był tam głównie z żałobą i pokutą, praktykowany szczególnie po klęskach spadających na całą społeczność. Tendencje ascetyczne, których wyrazem było m.in. wyłączenie z jadłospisu wina i mięsa, widoczne były wyraźnie w judeochrześcijaństwie ${ }^{3}$. Chrześcijanie uczynili z postu regularną praktykę. Post połączony z modlitwą był cechą wyróżniającą pobożność chrześcijańską. Zasadniczym zaś, od IV wieku, czasem praktykowania wstrzemięźliwości pokarmowej był okres czterdziestodniowego postu przed świętem Wielkanocy oraz dwa dni w tygodniu - środa i piątek. Post praktykowali również katechumeni przed przyjęciem chrztu oraz pokutnicy ${ }^{4}$. W niezwykle surowy sposób praktykowali post asceci i mnisi ${ }^{5}$. Poprzez umartwienie ciała starano się przezwyciężyć właściwe cielesnej naturze namiętności, które oddawały człowieka pod władzę szatana. Umartwienie ciała postami miało przywrócić w życiu człowieka właściwe miejsce jego naturze duchowej ${ }^{6}$.

W korespondencji Hieronima znajdują się świadectwa na temat, jak on sam podczas swojego pobytu na pustyni pościł i dokonywał innych praktyk ascetycznych, aby uwolnić ciało od pożądliwości: „brudna skóra przybrała kolor etiopskiego ciała. Codziennie łzy, codziennie westchnienia, a jeśli mnie kiedyś, mimo że się opierałem dopadł nagły sen, kładłem ledwie trzymające się razem kości na gołej ziemi. Nie mówię już o umartwieniach w pokarmie i napoju, gdyż nawet chorzy mnisi używają tylko zimnej wody, a przyjęcie czegoś gotowanego uważaliby za zbędne. [...] Bladły mi usta z postów, a umysł napełniał

\footnotetext{
3 Por. S. Bralewski, Praktykowanie postu w świetle historiografii kościelnej IV-V wieku, „Vox Patrum”, 33/2013, t. 59, s. 359-360.

4 Por. ibidem, s. 377.

Znakomicie obraz życia ascetki, która żyła w mieście jak na pustyni, przedstawia Hieronim w jednym ze swoich listów, w którym opisuje życie jednej ze swoich duchowych podopiecznych, Aseli: „tak skromnie się zawsze zachowywała i ukrywała się w tajnikach swojego mieszkania, że nigdy kroku nie zrobiła na oczach ludzi, nigdy z mężczyzną nie rozmawiała i - co więcej jeszcze godne podziwu - siostrę dziewicę raczej kochała, niż widywała. Pracowała rękami swoimi [...]. Z Oblubieńcem rozmawiała albo się modląc, albo śpiewając psalmy; do grobów męczenników śpieszyła prawie niewidzialna i gdy się cieszyła ze spełnienia swojego zamiaru, to radość jej powiększało to, że nikt jej nie poznał. Gdy przez cały rok nieustannie praktykowała posty, po dwa i trzy dni w nich trwając, dopiero w Wielkim Poście okrętu swojego rozwijała żagle, przez wszystkie tygodnie radosne ukazując oblicze. [...] samotność uważała za rozkosz i w hałaśliwym mieście znajdowała pustelnię klasztorną". List 24,4, t. 1, s. 117-118. 6 Por. S. Bralewski, Od obżarstwa do postu-praktykowanie wstrzemięźliwości od pokarmu przez chrześcijan do VII w., w: Dietetyka i sztuka kulinarna antyku i wczesnego Bizancjum (II-VII w.), cz. II: Pokarm dla ciała i ducha, red. M. Kokoszko, Wydawnictwo Uniwersytetu Łódzkiego, Łódź 2014, s. 521.
} 
się pożądaniami i w umarłym już prawie ciele kotłowały się tylko żądze" . Hieronim więc, walcząc z pokusami pożądliwości, maltretował wręcz swoje ciało, spożywając niewielką ilość zimnego pokarmu i pijąc tylko zimną wodę. Podczas pobytu na pustyni w sposób skrajny, wyczerpujący dla organizmu, praktykował post i inne formy umartwienia ciała. Tak skrajnego postu i innych umartwień ciała zapewne nie stosował przez całe swoje życie. Można tak sądzić np. na podstawie tego, że w jego listach, i to z różnego okresu jego działalności, znajduje się wiele wypowiedzi, w których nie pochwala tak skrajnej postawy u innych.

Hieronim przestrzega mnichów, aby nie utożsamiali postu z głodówką, przypominając, że diabeł może skusić ich właśnie głodem ${ }^{8}$. W liście do Eustochium, który jest swoistego rodzaju epitafium jej matki Pauli, Hieronim, pisząc o praktykowanych przez Paulę postach, uznaje że przekraczała w nich umiar i w ten sposób zbytnio osłabiała swoje ciało. Z wyjątkiem dni świątecznych, jak stwierdza autor listu, jej jedynym pokarmem była oliwa ${ }^{9}$. Hieronim wspomina także o pewnej ekscentrycznej grupie mnichów, których określa mianem „remboci". Jest to najgorszy i bardzo zaniedbany rodzaj mnichów. Hieronim poddaje surowej krytyce także ich postawę w sprawie postu. „Mają zwyczaj współzawodniczyć w postach, a to, co powinno być tajemnicą, robią przedmiotem zwycięstwa. [...] a gdy przyjdzie dzień uroczysty, objadają się aż do wymiotów" nej strony czynią post przedmiotem współzawodnictwa, co bez wątpienia przynajmniej u „zwycięzców” związane było z głodówką skrajnie wycieńczającą organizm, z drugiej w dni świąteczne dopuszczają się obżarstwa.

Hieronim zdecydowanie sprzeciwia się obu skrajnościom, dlatego w praktykowaniu postu opowiada się za rozsądkiem i umiarem. Ten jego rozsądek i umiar można dostrzec $w$ radzie, jakiej udziela wdowie Furii: „Skromny pokarm i żołądek zawsze łaknący należy wyżej cenić niż trzydniowe posty; i o wiele lepiej jest codziennie mało przyjmować niż rzadko do sytości. Ten deszcz jest najlepszy, który powoli spada na ziemię - nagła i ulewna nawałnica przewraca zupełnie glebę" "I. W poście chodzi o zasadę stosowania „złotego środka”, o stałą postawę wstrzemięźliwości i unikanie postaw skrajnych. Podobnej porady udziela Hieronim mnichowi Rustykowi: „Nie szukaj leku w kąpieli, jeśli żar ciała pragniesz gasić zimnem postów. Niechaj te jednak będą umiarkowane, aby nie osłabiły zbytnio żołądka, a domagając się następnie wskutek tego większego posilania, nie przerodziły w obżarstwo, z którego rodzi się namiętność. Skromny i umiarkowany pokarm jest pożyteczny i dla ciała, i dla duszy” ${ }^{\text {" }}$. Podobna porada, jak należy pościć z rozsądkiem i umiarem, by post nie spowodował uszczerbku na zdrowiu, znajduje się także w liście do Demetriady. Wstrzemięźliwość nie może cechować się brakiem umiaru i przesadą. Wtedy nie jest ona cnotą, lecz wadą. Dlatego Hieronim napomina Demetriadę, czego w praktyce postu powinna unikać: „Nie powinnaś tak pościć, byś drżała i zaledwie mogła oddychać, i żeby cię towarzyszki niosły na rękach lub podtrzymywały, lecz tak, byś złamawszy pożądliwość ciała ani w czytaniu, ani w psalmach,

\footnotetext{
List 22, 7, t. 1, s. 86.

Por. List 3,5, t. 1, s. 9.

List 108,17 , t. 3, s. 174 .

List 22,34, t. 1, s. 106.

List 54,10 , t. 2, s. $42-43$.

12 List 125,7, t. 4, s. 156.
} 
ani w czuwaniach nie czyniła mniej niż zwykle"r3. Post nie jest celem samym w sobie i nie może być przeszkodą w wypełnianiu innych obowiązków życia chrześcijańskiego. Wskazuje na to zdanie, którym Hieronim konkluduje swoje skierowane do Demetriady pouczenie: „Post nie jest doskonałą cnotą, lecz fundamentem innych cnót” ${ }^{\text {I4 }}$. Dlatego w innym z listów skierowanym do Eustochium, Hieronim w jeszcze bardziej dosadny sposób podkreśla, że post nie jest celem sam w sobie, lecz u jego podstaw znajdują się inne cele: „Umartwiamy się bowiem nie dlatego, żeby Bóg [...] znajdował upodobanie w burczeniu naszych wnętrzności i w próżnym żołądku oraz gorączce płuc, ale że w inny sposób nie można uchronić czystości”' Celem postu jest ukształtowanie i rozwój w człowieku cnót, które stanowią o chrześcijańskim sposobie życia. Z taką myślą zwraca się również Hieronim do Celancji: „A na co zda się wycieńczać ciało wstrzemięźliwością, jeśli umysł nadyma się pychą? Na jaką pochwałę zasłużymy za bladość spowodowaną postem, jeśli jesteśmy sini z zawiści? Cóż to za cnota nie pić wina, a upijać się gniewem i nienawiścią? Wtedy, powiadam, znakomita jest wstrzemięźliwość, wtedy piękne i wspaniałe poskramianie ciała, gdy dusza pozbywa się wad"'.

Co więc jest według św. Hieronima istotą postu? O co tak naprawdę w poście chodzi? Zwłaszcza tym, którzy nie odróżniają postu od głodówki, Hieronim z właściwą sobie barwnością i wyrazistością odpowiada, że Bogu nie chodzi o burczenie w brzuchu. Raz jeszcze należy powtórzyć istotną myśl autora, że post jest fundamentem innych cnót. Wyprowadzając z tej ostatniej myśli Hieronima pewne wnioski, można powiedzieć, że post jest potrzebny po to, aby lepiej żyć i funkcjonować w świecie, we wspólnocie ludzkiej i w Kościele, a lepiej żyć i pracować na rzecz wspólnoty Kościoła może tylko człowiek zdrowy fizycznie i psychicznie. W poście chodzi o lepszą jakość życia. Hieronim nauczający o rozsądnym umiarkowanym poście to nie tylko moralista i kierownik życia duchowego, ale jakby lekarz i dietetyk, który doradza, jak zdrowo żyć i lepiej pracować.

\section{Dieta człowieka późnego antyku w kręgu śródziemnomorskim}

Jak wyglądała codzienna dieta przeciętnego mieszkańca kręgu śródziemnomorskiego w czasach św. Hieronima? Podstawowym produktem spożywczym dla większości mieszkańców Cesarstwa Rzymskiego był chleb. Autorzy późnego antyku, mówiąc o chlebie jako podstawowym produkcie żywnościowym, mają zazwyczaj na myśli jego pośledni gatunek, mianowicie chleb jęczmienny (panis cibarius). Inny gatunek chleba wypiekany z pszennej mąki (panis candidus, panis siligneus) uchodził wówczas za luksusowy towar spożywczy'17, chociaż był lepszy zarówno z kulinarnego jak i dietetycznego punktu widzenia. Zawarty w pszenicy gluten sprawiał, że, w przeciwieństwie do jęczmienia, powstała z niej mąka nadawała się lepiej do wypieku chleba, gdyż pozwalała na wyrośnięcie ciasta i tym samym

13 List 130,11, t. 4, s. 201.

14 Ibidem.

15 List 22,11, t. 1, s. 88.

16 List 148,22, t. 5, s. 104.

17 Por. I. Milewski, Dieta człowieka późnego antyku $w$ relacjach łacińskich i greckich autorów chrześcijańskich epoki, ,Vox Patrum”, 33/2013, t. 59, s. 380. 
dawała pulchne pieczywo. Wysokie ceny pszenicy czyniły jednak z jęczmienia pożywienie łatwiej dostępne i częściej konsumowane, zwłaszcza przez mniej zamożnych mieszkańców ${ }^{18}$.

$\mathrm{Na}$ temat wartości dietetycznej chleba jęczmiennego piszą antyczni medycy. Galen w dziele De alimentorum facultatibus podkreśla, że chleb jęczmienny różni się pod względem dietetycznym od chleba z mąki pszennej. Różnica ta polega na braku lepkości, która wpływa na stosunkowo niską pożywność chleba jęczmiennego. Objawia się także w fizycznych właściwościach pieczywa, które jest kruche. Medyk stwierdził, że generalnie stosunkowo niska wartość odżywcza chleba z jęczmienia zależy od jakości ziarna, które wykorzystano do wypieku. Im lepszy gatunkowo surowiec, tym więcej wartości odżywczych dostarcza organizmowi sam produkt. Galen stwierdza także, iż jęczmień znacznie różni się swoimi cechami od pszenicy. W przeciwieństwie do tej drugiej, nie rozgrzewa, a jest wyraźnie chłodzący ${ }^{19}$.

Oprócz chleba istotną część pożywienia mieszkańców basenu Morza Śródziemnego stanowiły warzywa. W literaturze późnego antyku pojawiają się one jednak jako pożywienie uzupełniające i zastępcze. W różnych pracach medycznych zachowały się liczne rady, w jaki sposób przyrządzić rośliny zielone tak, aby wykorzystać ich ograniczone walory odżywcze i właściwie spożytkować działanie farmakologiczne. Można je uznać za sui generis postulatywny poradnik zdrowego odżywiania oparty na ówczesnej praktyce gastronomicznej w tym zakresie ${ }^{20}$.

Autorzy późnego antyku, mówiąc o podstawowych produktach żywieniowych, wspominają także o rybach ${ }^{21}$. We współczesnych badaniach przyjęło się z reguły uważać, że ryby odgrywały istotne znaczenie $w$ diecie ludzi żyjących $w$ okresie antyku i Bizancjum. Nie są jednak znane dane statystyczne, które odzwierciedlałyby popularność ich poszczególnych gatunków. Dobre i świeże ryby, a także wyrabiane z nich przetwory były jednak zasadniczo drogie, dlatego nie stanowiły nigdy podstawy codziennej diety, która zarówno w okresie antycznym, jak i bizantyńskim nadal oparta była na produktach uzyskiwanych ze zbóż i roślin strączkowych, na jarzynach i owocach ${ }^{22}$.

Mięso w krajach śródziemnomorskich nie było podstawowym produktem w menu ich mieszkańców. Po części można to wytłumaczyć jego wysoką ceną, która ograniczała krąg jego nabywców $w^{23}$. Notabene ów schemat wyżywienia utrzymał się do dnia dzisiejszego i jest typowy dla tak zwanej kuchni śródziemnomorskiej. Powodów tego zjawiska jest wiele, ale najistotniejszym spośród nich jest zespół cech naturalnych, które charakteryzują regiony położone nad Morzem Śródziemnym. Obszar śródziemnomorski nie sprzyja hodowli zwierząt przeznaczonych na mięso na masowa skalę. Sezon wegetacyjny roślin jest tam stosunkowo krótki, a bujność wiosennej flory szybko przemija z powodu cyklicznego niedostatku opadów,

18 M. Kokoszko, J. Dybała, K. Jagusiak, Z. Rzeźnicka, Dieta mnichów syryjskich. Komentarz do terminu „ar-

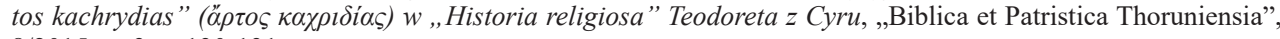
8/2015, nr 3, s. 130-131.

19 Por. ibidem, s. 141-142.

20 M. Kokoszko, K. Jagusiak, Z. Rzeźnicka, Pokarm dla zdrowia ciała. Rośliny strączkowe, warzywa, mięso oraz produkty zwierzęce, w: Dietetyka i sztuka kulinarna antyku i wczesnego Bizancjum (II-VII w.), cz. II: Pokarm dla ciała i ducha, red. M. Kokoszko, Wydawnictwo Uniwersytetu Łódzkiego, Łódź 2014, s. 127-132.

21 Por. I. Milewski, op. cit., s. 381.

22 M. Kokoszko, K. Jagusiak, Z. Rzeźnicka, Morskie rarytasy: opinie wybranych antycznych i bizantyńskich autorów o rybach z rodzaju thunnus, „Piotrkowskie Zeszyty Historyczne”, 13/2012, s. 11-13.

23 Por. I. Milewski, op. cit., s. 381. 
który w połączeniu z wysoką temperaturą powoduje sezonowe wysuszenie naturalnych pastwisk, co oczywiście nie wpływa korzystnie na rozwój i produktywność trawożernych zwierząt, gdyż nie tylko hamuje przyrost tkanki, ale także zmniejsza mleczność24.

Jak wyglądało z kolei spożycie mleka przez człowieka antyku? Mleko jako produkt spożywczy jest trudny do przechowywania, szybko ulega fermentacji. Zapewne więc jego spożycie przez mieszkańców miast było znikome. Nieco inaczej przedstawiała się sprawa na terenach wiejskich, gdzie pozyskiwano i spożywano świeży produkt, albo też przetwarzano go na $\operatorname{ser}^{25}$.

Ważną pozycją w diecie człowieka starożytności było wino. W przeważającej większość (ze względów zapewne finansowych) pito trunki pospolite, na jakie pozwolić mógł sobie nawet człowiek biedny. Spożycie takiego wina miało również inne uwarunkowania, chociażby brak szerszego dostępu do świeżej wody pitnej wymuszał po części również picie wina bardziej rozcieńczonego, wina rzeczywiście pośledniego gatunku, które swą zawartością procentową alkoholu konserwowało świeżą wodę użytą do jego rozcieńczenia. Oczywiście, ze względów smakowych czy też leczniczych, wysoko ceniono wina lepszego gatunku, które - rzecz jasna - uzyskiwały również wysokie ceny ${ }^{26}$.

\section{Porady dietetyczne św. Hieronima}

Jak wyglądała codzienna dieta samego Hieronima? W jego korespondencji wzmianki na ten temat są tylko okazjonalne, ale pozwalają poznać niektóre szczegóły na temat produktów przez niego spożywanych. W jednym z listów Hieronim wspomina, że w jego domu rodzinnym codziennym pokarmem było proso (milium) i wspomniany już wcześniej chleb jęczmienny (panis cibarius) ${ }^{27}$. Proso spożywano od wieków i także dzisiaj dla wielu ludzi stanowi podstawę diety ${ }^{28}$. Należy ono do najstarszych roślin uprawnych. W starożytności było rozpowszechnione w Azji i Europie ${ }^{29}$. Roślina ta jest bardzo dobrym źródłem składników odżywczych, witamin, minerałów i związków organicznych, które mogą znacznie polepszyć kondycję organizmu. Dostarcza dużo energii, a także cennych kwasów tłuszczowych i witamin $\mathrm{z}$ grupy $\mathrm{B}^{30}$.

W innym z listów Hieronim pisze: „bobem napełniam swój żołądek” ${ }^{\mathrm{I}}$. Bób należy do roślin strączkowych. Już w starożytności był bardzo istotnym źródłem pożywienia. Nie należał też do produktów drogich. Bób należy do pokarmów, które zostały bardzo szczegółowo scharakteryzowane w antycznych i bizantyjskich źródłach medycznych. Grecki lekarz, farmakolog i botanik Dioskurydes utrzymywał, że bób przyczynia się do powstania w organizmie powietrza i innych gazów, jest trudny do wstępnego strawienia, a nadto powoduje

\footnotetext{
24 Por. M. Kokoszko, K. Jagusiak, Z. Rzeźnicka, Pokarm dla zdrowia ciała, op. cit., s. 213-214.

25 Por. I. Milewski, op. cit., s. 381.

26 Por. ibidem, s. 382-383.

27 List 52,6, t. 2, s. 17.

28 Por. Właściwości zdrowotne prosa (kaszyjaglanej), http://tipy.interia.pl/artykul_25670,wlasciwosci-zdrowotneprosa-kaszy-jaglanej.html (dostęp: 3.03.2017).

29 Por. M. Babalski, K. Przybylak, Z. Przybylak, Odkrywamy ekologiczne proso i kasze jaglana, http://biokurier. $\mathrm{pl} /$ component/content/article?id=778:odkrywamy-ekologiczne-proso-i-kasze-jaglana (dostęp: 18.05.2019).

30 Por. Proso - właściwości zdrowotne i zastosowanie zboża, http://www.exitdoor.pl/zdrowie-i-uroda/wlasciwosci-zdrowotne-prosa/ (dostęp: 3.03.2017).

31 List 45,5, t. 1, s. 184: „Ego faba ventrem impleo”.
} 
złe sny. Zapobiega kaszlowi. Zielony bób jest niedobry dla żołądka, a ponadto wiatropędny. Z kolei starożytny lekarz Orybazjusz zaklasyfikował bób jako pokarm o dobrych sokach, ale jednocześnie stwierdził, że jego nasiona są trudne do wstępnego strawienia ${ }^{32}$. Warto jednak zaznaczyć, że bób charakteryzuje się wysokimi wartościami odżywczymi przy stosunkowo niskiej zawartości kalorii. Cechuje się znaczną zawartością błonnika pokarmowego i niską zawartością tłuszczu, co sprawia, że bób może być stosowany przez osoby chcące schudnąć lub ceniące prawidłowo zbilansowaną dietę33. Bób wpływa na obniżenie stężenia cholesterolu i tym samym pomaga regulować ciśnienie krwi. Dzięki zawartości błonnika reguluje pracę jelit, powoduje uczucie sytości i sprawia, że rzadziej sięga się po przekąski ${ }^{34}$. Zapewne i z tych ostatnich względów Hieronim często sięgał po bób. Można też przyjąć, że w diecie omawianego autora znajdowały się również te pokarmy i napoje, których stosowanie zalecał innym.

W liście do Eustochium Hieronim zaleca stosować proste pokarmy, a nie dogadzać swojemu podniebieniu. Powołując się na Pismo Święte, wskazuje, że poczesne miejsce w diecie człowieka powinno mieć to, co najprostsze: chleb i woda ${ }^{35}$. Dieta powinna się charakteryzować przede wszystkim umiarkowaniem w jedzeniu i piciu, dlatego w liście do Eustochium Hieronim zwraca się do niej w następujących słowach: „Pokarm twój niech będzie umiarkowany, a żołądek nigdy nie przepełniony. Bo bardzo wiele jest takich, które wstrzymują się od wina, ale nadużywają pokarmów"36. Z kolei do wdowy Salwiny pisze: „wystarcza tania jarzyna, razowy chleb, skromny pokarm i napój” ${ }^{37}$. Natomiast zmęczonej uciążliwościami życia w Rzymie Marceli doradza: ,jak można tylko najprędzej udajmy się w zacisze wiejskie, jakby do portu. Tam chleb zwykły i warzywa naszymi rękami podlewane, mleko, przysmak wiejski, skromne wprawdzie, ale wystarczające dają pożywienie. Prowadzącemu taki tryb życia w modlitwie nie przeszkodzi sen, a w czytaniu przejedzenie. W lecie rozłożyste drzewo użyczy schronienia; jesienią sama łagodność powietrza i rozesłane pod drzewem liście wskazują miejsce odpoczynku. Na wiosnę maluje się pole kwiatami, a wśród gwaru ptaków przyjemniej odmawiać psalmy. Jeśli przyjdzie mróz i zimowe śniegi, drzewa nie będę dokupywał, czujniej spać lub czuwać będę. I wiem na pewno, że nie zmarznę"38. Odpowiednia jarska dieta, świeże powietrze i odpoczynek mają zapewnić Marceli powrót do sił fizycznych i duchowych oraz lepsze funkcjonowanie w życiu społecznym.

Szczególna wartość porad dietetycznych św. Hieronima polega na dostosowaniu ich do człowieka. Przykładem może być bardzo ciekawy list Hieronima do młodej wdowy Furii, którą zachęca do wytrwania we wdowieństwie i podaje jej wskazówki, jak zachować czystość i dobre imię. Ma jej w tym dopomóc właściwa dla niej dieta. List ten i skierowane do adresatki porady dietetyczne świadczą o tym, że Hieronim dobrze znał dzieła antycznych medyków. Zważywszy na młody wiek adresatki Hieronim przywołuje fragment jednego

\footnotetext{
32 Kokoszko M., Jagusiak K., Rzeźnicka Z., Pokarm dla zdrowia ciała, op. cit., s. 96-115.

33 Por. J. Bylinowska, Bób - właściwości i wartości odżywcze, http://dietetycy.org.pl/bob-wlasciwosci-wartosci-odzywcze/ (dostęp: 3.03.2017).

34 Por. W. Misiuk, Bób - charakterystyka, właściwości, gotowanie bobu, https://portal.abczdrowie.pl/bob (dostęp: 3.03.2017).

35 List 22,10, t. 1. s. 88: „«Połóż przed nimi chleb i wodę, aby jedli i pili i poszli do swojego pana» $(2 \mathrm{Krl} 6,22)$ ”.

36 List 22,17, t. 1, s. 92.

37 List 79,4, t. 2, s. 238.

38 List 43,3, t. 1, s. 181.
} 
z dzieł Galena: „Mówią lekarze i ci, którzy pisali o naturze ludzkich ciał, głównie zaś Galen w księgach pod tytułem $O$ rzeczach dla zdrowia przydatnych, że ciała dzieci dorastających i młodzieńców oraz mężczyzn i kobiet w dojrzałym wieku płoną wrodzonym ogniem i że dla tych okresów życia szkodliwe są pokarmy podwyższające ciepłotę, a dobrze robi dla zdrowia wszystko, co zimne w pokarmie i napoju; jak, przeciwnie starcom, którzy cierpią zaflegmienie i zimno, pomagają ciepłe pokarmy i stare wina"39. Po przytoczeniu zasady Galena Hieronim przepisuje Furii następującą dietę. Po pierwsze, jej zwyczajnym napojem powinna być woda, z natury najzimniejsza. Jeśli jednak nie pozwalałoby na to słabe zdrowie, powinna spożywać nieco wina. Co do pokarmów, przede wszystkim powinna unikać gorących. Powinna ze swojej diety wykluczyć mięso. Jej pokarmem powinny być przede wszystkim jarzyny, jednak powinna unikać takich, które wzdymają i obciążają żołądek. Ponadto opinie starożytnych lekarzy Hieronim potwierdza cytatami z łacińskiej literatury klasycznej i z Pisma Świętego: „Dlatego i Zbawiciel mówi: «Strzeżcie się, abyście przypadkiem serc swoich nie obciążyli obżarstwem i opilstwem, i troskami tego życia» (Łk 2I,34). I Apostoł dodaje: «Nie upijajcie się winem, w którym tkwi rozpusta» (Ef 5,I8). [...] także komediopisarz [Terencjusz, Eunuch], którego celem jest znać obyczaje ludzkie i opisywać je, powiedział: «Bez Cerery i Libera marznie Wenera»"40. Przywołując biblijne postaci trzech młodzieńców i Daniela, to znaczy zaleca tak popularny dzisiaj post Daniela: „Dla nas nie jest to sprawa dbałości o ciało, którą u nich w takim doborze pokarmów widzimy [...], ale siły duszy, która wzmaga się przez słabość ciała"ł1. W słowach tych Hieronim chce powiedzieć Furii przede wszystkim to, iż w jej przypadku w poście Daniela chodzi o wypracowanie poprzez zmaganie się z ciałem siły ducha, co ułatwi jej zachowanie wstrzemięźliwości seksualnej i wytrwanie we wdowieństwie. Świadczą o tym następujące słowa św. Hieronima: „Stąd pochodzi, że niektórzy dążący do czystego życia upadają w połowie drogi, ponieważ za jedyną wstrzemięźliwość uważają wstrzymanie się od mięsa, a przeładowują żołądek jarzynowymi potrawami, które umiarkowanie i oszczędnie przyjmowane nie są szkodliwe. Mówię wyraźnie, co myślę - nic tak nie rozpala ciała i nie drażni organów rodnych jak niestrawiony pokarm i wstrząsy czkawki’"22.

O diecie dostosowanej do wieku św. Hieronim pisze także w liście do Lety, w którym udziela jej porad na temat wychowania córki. Porady dotyczą także diety pokarmowej. Hieronim zwraca adresatce uwagę, że przed dojściem do dojrzałości surowa wstrzemięźliwość jest dla młodych ludzi niebezpieczna. W związku z tym Hieronim zwraca się do Lety: „A do tego czasu, jeśli wymagać będzie potrzeba, niech i do łaźni chodzi, i wina po trochu używa ze względu na żołądek, a także i spożywaniem mięsa niech się pokrzepia, by nogi nie odmówiły posłuszeństwa, zanim zaczną biegać"43.

\section{Wnioski}

Kinga Wiśniewska-Roszkowska, znany lekarz i dietetyk, w jednej ze swoich książek zauważa: „Ludzie jedzący dużo mięsa powołują się zwykle na jego wartości odżywcze [...]. Ogólnie

\footnotetext{
39 List 54,9, t. 2, s. 41-42.

40 List 54,9, t. 2, s. 42.

41 List 54,10, t. 2, s. 42.

42 Ibidem.

43 List 107,8 , t. 3, s. 155.
} 
powiedzieć można, że jest ono pokarmem cennym, lecz obarczającym i uciążliwym dla ustroju. Wymaga też dużej sprawności narządów oczyszczających ustrój (wątroba, nerki). Wzgląd na zdrowie nakazuje ograniczać pokarmy mięsne zwłaszcza w drugiej połowie życia. Zresztą, mięso może być bez szkody nawet całkowicie wyłączone, jeżeli w diecie uwzględnia się nabiał. Obserwacje zdrowych i sprawnych starców w ośrodkach długowieczności wykazują, że jadają oni mięso rzadko, ale nie są ścisłymi jaroszami. Wyżywienie ich składa się głównie z jarzyn, owoców, ciemnego pieczywa, mleka i sera, natomiast prawie nie używają białej mąki i cukru"44. Hieronim niemal całkowicie wykluczał mięso z diety. Dopuszczał je ewentualnie w niewielkich ilościach w procesie dojrzewania młodych ludzi. Wspomniana autorka stwierdza także: ,prawidłowa, profilaktyczna dieta powinna być głównie mleczno-jarska (mleczno-roślinna), z dużą ilością owoców i surówek i ze znacznym ograniczeniem mięsa, tłuszczów zwierzęcych, soli, cukru i słodyczy”45. Około I6oo lat temu św. Hieronim, opierając się na Piśmie Świętym, pismach klasyków oraz własnym doświadczeniu, polecał dietę, której wartość potwierdzają dzisiejsze medycyna i dietetyka.

\section{Fasting and prevention of its possible health effects in the light of St. Jerome's correspondence}

Abstract

In this article the author deals with the issue of health care, which Jerome addresses in his letters to ascetics who, in many cases, by their extreme approach to the practice of fasting, destroy their health. On the one hand, Jerome teaches them how to understand and practice fasting in the Christian sense, and on the other hand, similar to today's dietitians, he tries to suggest a proper diet in such a way that it is possible to practice Christian fasting and lead one's life in accordance with the monastic vocation, while maintaining both spiritual and bodily health.

Key words: Saint Jerome, fasting, asceticism, health, diet

\section{BIBLIOGRAFIA}

\section{Źródła}

Hieronim ze Strydonu, Listy, t. I-5, wstęp i oprac. na podst. tłum. ks. J. Czuja, M. Ożóg, tekst łaciński H. Pietras SJ, Kraków 20I0-20I3, Źródła Myśli Teologicznej, t. 54, 55, 6I, 63, 68.

\section{Opracowania}

Bralewski S., Od obżarstwa do postu-praktykowanie wstrzemięźliwości od pokarmu przez chrześcijan do VII w., w: Dietetyka i sztuka kulinarna antyku i wczesnego Bizancjum (II-VII w.), cz. II: Pokarm dla ciała i ducha, red. M. Kokoszko, Wydawnictwo Uniwersytetu Łódzkiego, Łódź 20I4, s. 463-52I.

Bralewski S., Praktykowanie postu w świetle historiografii kościelnej IV-V wieku, „Vox Patrum", 33/20I3, t. 59, s. 359-377.

44 K. Wiśniewska-Roszkowska, Asceza, moralność, zdrowie, Instytut Wydawniczy PAX, Warszawa 1980, s. 110.

45 Ibidem, s. 220. 
Formela M., Św. Hieronim jako kierownik życia duchowego w świetle jego korespondencji. Studium historyczno-patrystyczne, rozprawa doktorska napisana pod naukowym kierownictwem ks. dra hab. Tadeusza Kołosowskiego, prof. UKSW, Warszawa 2004.

Kokoszko M., Jagusiak K., Rzeźnicka Z., Pokarm dla zdrowia ciała. Rośliny straczkowe, warzywa, mięso oraz produkty zwierzęce, w: Dietetyka i sztuka kulinarna antyku i wczesnego Bizancjum (II-VII w.), cz. II: Pokarm dla ciała i ducha, red. M. Kokoszko, Wydawnictwo Uniwersytetu Łódzkiego, Łódź 20I4, s. 53-75.

Kokoszko M., Dybała J., Jagusiak K., Rzeźnicka Z., Dieta mnichów syryjskich. Komentarz do

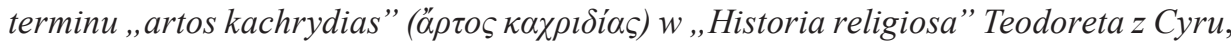
„Biblica et Patristica Thoruniensia”, 8/20I5, nr 3, s. I23-I56.

Kokoszko M., Jagusiak K., Rzeźnicka Z., Morskie rarytasy: opinie wybranych antycznych i bizantyńskich autorów o rybach z rodzaju thunnus, „Piotrkowskie Zeszyty Historyczne”, I3/2OI2, S. II-25.

Kołosowski T., Święty Hieronim jako duszpasterz, „Seminare”, 20/2004, s. 453-464.

Milewski I., Dieta człowieka późnego antyku w relacjach łacińskich i greckich autorów chrześcijańskich epoki, „Vox Patrum”, 33/2013, t. 59, s. 379-386.

Wiśniewska-Roszkowska K., Asceza, moralność, zdrowie, Instytut Wydawniczy PAX, Warszawa I980.

\section{Strony internetowe}

Babalski M., Przybylak K., Przybylak Z., Odkrywamy ekologiczne proso i kaszę jaglana, https://biokurier.pl/jedzenie/odkrywamy-ekologiczne-proso-i-kasze-jaglana/ (dostęp: I8.05.20I9).

Bylinowska J., Bób - właściwości i wartości odżywcze, http://dietetycy.org.pl/bob-wlasciwosci-wartosci-odzywcze/ (dostęp: 3.03.20I7).

Właściwości zdrowotne prosa (kaszyjaglanej), http://tipy.interia.pl/artykul_25670,wlasciwoscizdrowotne-prosa-kaszy-jaglanej.html (dostęp: 3.03.20I7).

Misiuk W., Bób - charakterystyka, właściwości, gotowanie bobu, https://portal.abczdrowie. $\mathrm{pl} /$ bob (dostęp: 3.03.20I7).

Proso - właściwości zdrowotne i zastosowanie zboża, http://www.exitdoor.pl/zdrowie-i-uroda/wlasciwosci-zdrowotne-prosa/ (dostęp: 3.03.20I7). 